\title{
ELECTRICITY INSTALLATION SKILLS TRAINING IN RINONDORAN VILLAGE COMMUNITY, LIKUPANG EAST MINAHASA SUB-DISTRICT, NORTH MINAHASA
}

\author{
F. J Tasiam \\ Universitas Negeri Manado \\ ftasiam@unima.ac.id
}

\begin{abstract}
Abstrak
This service aims to create jobs in the field of repairing and installing electrical installations in Rinondoran village, Likupang sub-district, East Minahasa Utara.

The target audiences in this training are families in place to repair / revise electrical installations in community homes, community leaders, religious leaders, government in the village, PKK leaders, in general this skills training is directed at all communities in Rinondoran Village. Likupang Timur District, Minahasa Utara North Sulawesi

The method used in this training is the direct experimental method, namely directly repairing / revising from house to house in the Rinondoran community of East Likupang District. While repairing / revising explains the cause and effect of the damage

The result of this dedication. The community can do the electricity installation well, not only in their village, but in other villages. This can increase income in his village.
\end{abstract}

Key word: Electrical Installation Skill

\section{INTRODUCTION}

The target of this community service in Rinondoran Kec. Likupang Timur, North Minahasa

North Sulawesi Province. Rinodoran Village has 269 Family Heads spread across five guardhouses. Each guard has a guard chief, each of which is responsible to the Village Head. In handling residents' problems, the head of each body manages the area according to the designated area.

The livelihoods of the population are not evenly distributed, there are Civil Servants, ABRI, Retired ABRI, Retired Civil Servants, Builders, Farmers and the private sector. In general, people in Rinondoran Village have a livelihood as farmers and the community economy is quite adequate. Thus the community can follow the development of existing science and technology when compared to other places

Judging from the supporting facilities owned in the village of Rinondoran, it has sufficient facilities. Where it has entrepreneurial activities such as car repair shops, welding workshops, furniture manufacturing places, gypsum, has places of worship such as mosques, GMIM churches, Pentecostal churches, Bethel churches and Adventist churches. Besides that, it has a Puskesmas. In general, people in Rinondoran Village have Islam and Protestant religions. Other supporting facilities that are no less important in Rinondoran Village are 
electricity from PLN, telephone from Telkom and having a mobile phone that can be used properly. The asphalt road has reached the alleys. This facility is very supportive in various aspects in Rinondoran Village, Likupang Timur District, North Minahasa

In terms of electricity flow, it can be said that all people in Rinondoran Village can be reached by electricity from PLN and it can be said that the people in Rinondoran Village already have electricity from PLN. This electricity flow is paid monthly by the public to PLN in accordance with the amount of electricity used. The more electricity you use, the more the community must pay to PLN. On the other hand, the less electricity is used, the less people pay to PLN.

In terms of public knowledge about the flow of electricity, in general, people only know how to turn on and turn off electricity. The general public does not yet know how to use electricity effectively and efficiently. In addition, if viewed from the attitude of the community towards electricity, in general, people are afraid of electricity, not to be electrocuted, because the public thinks that electricity is very dangerous, even though the community already feels the benefits are quite large. Therefore, if there is even a little damage to electricity, the people are generally afraid to handle it themselves and they are more likely to be left alone or call an expert to handle it. To call an expert, of course the community must prepare a fee to pay and in general the community does not know the standard of payment for electricity work. If this is allowed to continue to allow the community to use the electricity out of place, it can result in a waste of electricity which can be followed by a waste of funds. In addition, it can increase the damage to various electrical equipment and also increase the danger due to electricity.

From the explanation above, skills in electricity installation are needed by the community in Rinondoran Village, Likupang Timur District, North Minahasa. For this reason, an Electrical Installation Skills Training for the Community in East Likupang District.

Rinondoran Village was held The results of this training are expected to provide skills on electrical installation for the community so that they can use electricity effectively and efficiently, if this happens it can result in savings in electrical energy which can be followed by economic or financial savings. In addition, the results of this training can provide skills for the community on ways to extend the usage life of household electric appliances that are used and can reduce hazards caused by electricity. In addition, these results can also provide skills on household electrical installations for the community, so that if there is damage to 
household electrical appliances, they can do it themselves.

\section{METHODS}

The method used in this training is the direct experimental method, namely directly repairing / revising from house to house in the village community of Rinondoran. While repairing / revising explains the cause and effect of the damage. In addition, all consumption and equipment are prepared by the organizer of this training. The training activities start from planning to submitting proposals, after being approved, conducting a site inspection to training and compiling reports. Time used until reporting three months. Implementation of training in the Even Semester of 2019/2020. Previously, consultations had been held about the time and place of the training with Rinondoran Village Head, Likupang Timur District, North Minahasa. This consultation also concerns the technicalities of the training being carried out

\section{RESULTS AND DISCUSSION}

\section{A. Activity Results.}

The results of direct observations after completing the electrical installation work training in Rinondoran Village, East Likupang District, it was seen that the community began to raise awareness of using electricity. In addition, every electric tool is always studied not only to turn on or turn off an electric appliance but to how to care for and repair the damage that has occurred.

Some changes that can be seen clearly in the use of electricity by the community in Rinondoran Village, East Likupang District, among others:

a. People often control the electric lights that are used and often any lights that are not used are always turned off.

b. People do not place the lights too high or too low and place according to the object to be illuminated.

c. For certain lighting, for example using a computer, typing or writing, electric lighting is made focused and its rays do not spread anywhere. This makes the use of electric power efficient.

d. Previously, they studied the manual carefully and if they had trouble, they asked the dealer where to buy the appliance. Besides asking questions on this exercise. The household electrical appliances that are used first also study the illuminated furniture such as power, current and voltage on the appliance.

e. In the use of electricity, people often use safety equipment. For example, every time they work on electric tools, they use rubber sandals. Unlike before, they paid no heed to it.

f. Minor damages that occurred in household electrical installations were 
done by themselves and the results were quite adequate. Before training they often brought in installers from outside the village so that it was a waste of time, cost and energy.

g. The public in general already knows about electrical installation regulations through the general electrical installation regulations (PUIL) as well as books on electrical installations.

h. The community in general after completing this training they already know how to calculate electricity payments. Besides that, the payment of electricity is always on time, in the sense that it is rarely late in paying; again.

i. Each use of TL lamps provides the community with a condenser in accordance with the lamp power used, so that electricity savings can be obtained.

j. The electricity obtained is not only used for family needs, but is also used to increase income, for example, the refrigerator is used to sell various kinds of ice.

k. People always try to avoid danger due to electricity.

l. Electrical installations at home, people multiply the switch, making it easier to regulate electric lighting and efficient use of electric power can be achieved.
1. With electrical installation skills possessed, this is the creation of own employment.

$m$. The potential that exists in the community, including the population, can be utilized by training in electrical installation skills.

n. People will prefer to live in their village and be able to develop their own village through the electrical installation skills they acquire. Besides that, it can make them confident because they are respected by the general public. This can make the village well developed.

o. The community can do the electricity installation well, not only in their village, but it can be done in other places or in other villages. This can increase income in his village.

p. Minor damage to household electrical appliances was done by themselves and the results were quite adequate, before training they often brought in experts from outside the village.

q. Has reduced crime in his village because the community has the skills, even with these skills the community no longer consumes heavy drinking because these skills are fun for the community.

\section{B. Discussion}

After Rinondoran villagers in the Likupang Timur sub-district have participated in electrical installation skills training, they will 
make the best use of electricity or use electricity effectively and efficiently. This is possible by controlling the electric lamps used, they will immediately turn off the switch if the lamp is not in use. In addition, the public will know how to determine the distance of the lamp with the focus of its work, so that the light does not spread or is wasted in the sense that all the light emitted by the lamp can be used as much as possible. In addition, the lights do not need to be placed too far or too close, because if it is too far away then a lot. wasted light even if too close would allow dazzling eyes. So the placement of the lights does not need to be too far or too close, but it needs to be in accordance with the type of work to be done, or according to the work object.

They will learn the electric tools used after this training carefully through the instructions on the electric appliance, if they have trouble, they can ask the dealer or the competent person included in this training trainer. If this is the case, household electrical appliances will be used as well as possible and can last longer. In addition, if there is damage to electrical installations or household electric appliances, they will dare to repair or revise them because they already have sufficient electrical installation skills. In doing electrical work they will be more careful where before training they often do not use sandals, after this training they often use rubber sandals in working on electrical installations. So after this training they always use rubber sandals to do electrical work. In addition, the skills they have acquired look attractive to them, so they can read them through existing books or if they have trouble asking those who are competent, especially now that communication is easier because of the HP. Regarding the electricity consumption that must be paid, they can calculate by themselves so that they can find out how much to pay the electricity bill. That way they can find out the amount or lack of electricity consumption each month. This certainly can be a guideline for the community to make efficient use of electric power. In utilizing electric power, the community can seek additional income, by means of, among other things, selling various kinds of ice using the refrigerator. So the population in the village is not a burden but is utilized as a potential in the village in the context of developing the village. With the aforementioned matters, it becomes an attraction for people to stay happy in their village, in the sense that they will feel responsible if they leave their village. If this happens, it will reduce the movement of people from villages to cities. Before the training was held it allowed many young out of school youth to make trouble in the village or drink alcohol but after training where they have the skills in electrical installation. This can make them create their own employment 
opportunities so that welfare in the village can be achieved. With their electrical installation skills they will be able to make the best use of their time. Or it can be said that the available free time is used for personal, family and village interests. Including them being able to revise / repair electrical installations outside their village, this can increase their personal economy, including their families in their village. If this happens, it is possible that the welfare in the village will be achieved

\section{CONCLUSIONS AND}

\section{RECOMMENDATIONS.}

\section{Conclusion}

From the results of the activities as described above, it can be concluded that the results of the electrical installation skills training in Rinondoran Village, Likupang Timur District are as follows:

a. The implementation of the electrical installation skills training has gone according to the plan made in advance. In the implementation, there are no significant obstacles. It can be said that this training has achieved the expected goals.

b. This activity can contribute ideas to the people of Rinondoran village, East Likupang district. Where the community in general already has the skills in installing and renovating electrical installations. Besides that, you already know ways to make electric power efficient. c. This activity can stimulate the community to increase family income through their electrical installation skills.

c. The public can have an awareness of the importance of work safety equipment in carrying out electrical installation work.

d. Through this training, you can take advantage of the potential in the village, which can create your own job opportunities. Other things can reduce unemployment and can improve the economy in the village

\section{B. Suggestions}

a. Training activities like this need to be carried out in another village or kelurahan, if possible, they should be carried out every six months.

b. Training activities like this, if possible, the State Electricity Company (PLN) or an organization related to electricity can program it to be implemented throughout Indonesia in general and in North Sulawesi in particular.

c. Activities like this can be completed with electrical installation books. If possible in the village there is a library equipped with electrical installation books.

d. The public needs to learn about electrical installation regulations.

e. If possible in the village, a special working group will be created to revise and repair 
damaged electrical installations. If

possible, this working group will be included in the organizational structure in the village

\section{REFERENCES}

[1] jarif. 2012. Rencana-Rencana Hubungan Instalasi Listrik Penerangan Kotak Pos 204 Jakarta.

[2] Daryanto. 2015. Teknik Pengerjaan Listrik. PT Bumi Aksara. Jakarta

[3] Frank G. Grahan. 2005. Audels New Electric. Library. Theo, Audel \& Co Publisher. New York. NY. USA

[4] H.P.Richter.2003. Practical Electrical Wiring. MC. Graw-Hill Book Company. Inc.New York Toronto. London

[5] John M Nadon dan Bert J Gelmine. 2009. Industrial Electricity. Inc. Toronto New York London

[6] Moh. Hidayat. 2010. Instalasi Cahaya dan Tenaga. Teknik H. Stam Jakarta

[7] Perusahan Listrik Negara. 2014. Informasi Kelistrikan. Sulutteng :PLN Wilayah VII

[8] Trevor Linsley, 2015. Instalasi Listrik Tingkat Lanjutan Edisi ke tiga.

[9] Erlangga. Jakarta 